\title{
ERRÂNCIA E EXÍLIO NA SOUL MUSIC: do movimento Black-Rio nos anos 70 ao Q̨uarteirão do Soul em Belo Horizonte, 2010
}

\author{
Rita Aparecida da Conceição Ribeiro*
}

\section{Resumo}

No decorrer do século 20, presenciamos diversas diásporas. Algumas claramente abordadas pelos veículos de comunicação de massa, outras nem tanto. O presente trabalho pretende abordar o surgimento de um movimento de afirmação da identidade negra no Brasil, o movimento Black-Rio, surgido em meados dos anos 70, alvo de perseguição não apenas da ordem política, mas também dos veículos de comunicação até sua extinção, ainda na década de 70. A importância do Black-Rio confirma-se trinta anos depois, na constituição do Quarteirão do Soul em Belo Horizonte, movimento que tem ideário similar. Iniciado em 2004, no centro da cidade por um grupo de amigos, transformou-se em espaço de sociabilidade e afirmação da identidade negra. Assim como seu antecessor, começa a sofrer represálias.

Palavras-chave: Identidade negra. Soul music. Cultura de massas.

Nem todo pesquisador pode ser dar ao luxo de dizer que o seu objeto de pesquisa veio a seu encontro. Esse, porém, é o meu caso. Entender a questão urbana hoje, a partir da abordagem das formas simbólicas que permeiam a sociedade, ou seja, a partir dos fenômenos culturais, é uma tarefa que pressupõe vários tipos de recortes, pois a cidade se divide em diversos territórios constituídos por diferentes grupos sociais, que convivem às vezes em conflito, às vezes de maneira harmoniosa. Estes grupos desempenham papéis sociais, em momentos distintos, que muitas vezes se sobrepõem. Analisar as relações sociais no cotidiano pressupõe o exercício de uma percepção que extrapola uma determinada categoria analítica.

\footnotetext{
* Doutora em Geografia pela Universidade Federal de Minas Gerais. Professora do Programa de Pós-Graduação em Design da Universidade do Estado de Minas Gerais. E-mail: rita_ribeiro@uol.com.br
} 
Se os papéis e os usos da cidade se misturam, cabe ao pesquisador lançar mão de uma gama de categorias de análise que lhe permita ampliar sua visão, a partir da realidade focada.

Meu primeiro encontro com o objeto de pesquisa - o Quarteirão do Soul - se deu por acaso. Ao passar pelo referido quarteirão, dia 3 de abril de 2004, um tranquilo sábado à tarde, como são os do centro da cidade, me deparei com vários homens de meia-idade fazendo incríveis piruetas ao redor de um carro, dançando James Brown.

O Quarteirão do Soul localiza-se na região central de Belo Horizonte, na Rua Goitacazes, entre as ruas Curitiba e São Paulo ${ }^{1}$, basicamente um local de passagem durante a semana, mas que aos sábados, a partir das $14 \mathrm{~h} 00$, se transforma em pista de dança para homens e mulheres de meia-idade, advindos das mais diversas regiões da cidade, em sua maioria negros, trabalhadores de baixa remuneração: pintores, donas de casa, coveiros, cabeleireiras, taxistas, mecânicos, lavadores de carros e outras funções, que se encontram pelo prazer de ouvir e dançar a soul music.

A curiosidade a respeito da formação do movimento propiciou o contato com a diáspora negra, por mim interpretada a partir do viés de um produto midiático, a black music, e gerou a tese de doutorado, defendida em $2008^{2}$. Durante o período de quatro anos dediqueime a pesquisar o tema, entrevistando grande parte de seus idealizadores, tanto no Rio de Janeiro, quanto em Belo Horizonte. Para preservar o conteúdo das entrevistas, optamos por manter as falas como foram apresentadas, sem nos deter no apuro do idioma escrito.

\section{O surgimento da indústria do entretenimento no Brasil e a influência da soul music na afirmação da identidade negra}

A cultura de um povo é um dos seus determinantes. A discussão do conceito de cultura permeia diversas áreas do conhecimento, desde a sociologia, a antropologia, a história até, mais recentemente, a comunicação ${ }^{3}$. O estudo dos fenômenos culturais pode ser compreendido, como nos lembra Thompson (2002), como o estudo de um campo de significados constituídos a partir do mundo sócio-histórico. Ou seja, “o estudo das maneiras como expressões significativas de vários tipos são produzidas, construídas e recebidas por indivíduos situados em um mundo sócio-histórico” (THOMPSON, 2002, p. 165).

\footnotetext{
${ }^{1}$ Atualmente, o espaço deslocou-se para a Rua Tupis, esquina de Avenida Amazonas, na mesma região.

${ }^{2}$ RIBEIRO, Rita A.C. Identidade e Resistência no urbano: o Quarteirão do Soul em Belo Horizonte. IGCUFMG, 2008.

${ }^{3}$ Para uma maior discussão acerca do conceito de cultura, privilegiamos a abordagem de Williams (2007), Elias (1994), Gomes (2006) e Thompson (2002).
} 
A difusão dos veículos de comunicação de massa propiciou o desenvolvimento da cultura de massas. O poder de persuasão e convencimento das mídias foi usado em vários momentos de nossa história recente: como veículo de disseminação do ideário nazista, como elemento divulgador e incentivador da participação na Segunda Guerra Mundial, como catalisador do descrédito na Guerra do Vietnã. Sua influência se dá, muitas vezes, de forma tênue, pois nem sempre esses aparatos são percebidos como difusores de informação pelos usuários/ espectadores, como classifica Chauí:

Do ponto de vista do receptor, o aparelho de rádio e o televisor são eletrodomésticos, como o liquidificador ou a geladeira. Do ponto de vista do produtor, são centros de poder econômico (tanto porque são empresas privadas como porque são uma mercadoria que transmite e vende outras mercadorias) e centros de poder político ou de controle social e cultural (CHAUÍ, 2006, p.44).

As relações culturais também são fortes componentes das lutas políticas de um povo. Saunders (2008) apresenta no livro “Quem pagou a conta?” o relato das implicações da CIA (Agência Central de Informações) dos Estados Unidos na constituição de um projeto secreto de propaganda cultural, denominado Congresso pela Liberdade Cultural, dirigido por Michael Josselson, agente da CIA entre 1950 e 1967.

Em seu apogeu, o Congresso pela Liberdade Cultural tinha escritórios em 35 países, empregava dezenas de pessoas, publicava mais de vinte revistas prestigiosas, realizava exposições artísticas, contava com um serviço de notícias e reportagens, organizava conferências internacionais amplamente divulgadas e recompensava músicos e artistas com premiações e apresentações públicas. [...] a então incipiente CIA começou a construir, a partir de 1947, um "consórcio” cuja dupla tarefa era vacinar o mundo contra o contágio do comunismo e facilitar a aceitação dos interesses da política externa norte-americana no exterior (SAUNDERS, 2008, p. 13-14).

A cooptação do governo brasileiro à política norte-americana já havia gerado frutos na área da cultura durante o governo Vargas, estimulada pela política de boa vizinhança do governo Roosevelt: a migração de Carmen Miranda para os Estados Unidos, a participação de sua irmã, Aurora, no filme da Disney, "Você já foi à Bahia?”, que apresentava o personagem Zé Carioca, a vinda de Orson Welles para filmar o carnaval brasileiro ${ }^{4}$ que gerou muita polêmica e frustração para o diretor, que nunca conseguiu finalizar a obra.

\footnotetext{
${ }^{4}$ A esse respeito, ver Leaming (1987). Os gastos excessivos de Welles e a abordagem de temas como os jangadeiros desagradaram o governo Vargas e impediu sua conclusão, fato que o diretor lamentava: “A fé que tenho nesse filme chega às raias do fanatismo e você pode crer que, se It’s All True for parar no esquecimento, eu acabo indo junto” (LEAMING, 1987, p. 304).
} 
No início dos anos 60, o Congresso pela Liberdade Cultural voltava seus interesses para o Brasil, mas era visto com desconfiança, como afirmou um de seus agentes, Keith Botsford, para o agente John Hunt, em 29 de março de 1963, relatada por Saunders (2008):

Nessa ocasião ele disse a Hunt que os intelectuais brasileiros viam o Congresso como uma fachada "ianque", e sugeriu que a entidade se tornasse mais discreta, modesta e "invisível", só dando respaldo a projetos que tivessem um forte apoio local. Mas Hunt rejeitou essa abordagem, dizendo que nenhuma região do mundo devia ser negligenciada na luta contra o comunismo (SAUNDERS, 2008, p. 376).

A difusão do ideário norte-americano se dá principalmente pela difusão cultural de seus produtos midiáticos. Essa difusão toma impulso no Pós-guerra, com o acirramento da Guerra Fria. É nesse momento também que a indústria da comunicação de massas no Brasil sofre um grande impulso. Em 1959, o País possuía 525 estações de rádio AM (IBGE, 1959), 97 das quais situavam-se nas capitais. Em 1968, já existiam 788 emissoras AM (IBGE, 1970), 40 já com a novidade do FM. Do total de emissoras, 157 AM e 33 FM situavam-se nas capitais.

O consumo de aparelhos de rádio e, posteriormente, de televisão foi disseminado por todo o País, reforçando o ideário da modernização urbana. Ter acesso ao rádio e à TV promovia a noção de integração ao cotidiano dos grandes centros urbanos, de onde partia a maioria das transmissões. O modelo de consumo e de vida dos centros urbanos começa a se refletir pelo País e a promover mudanças no comportamento e na criação de novos hábitos de consumo da população ${ }^{5}$. Assim, o final dos anos 60, com as bênçãos e o incentivo do governo militar, encontra o Brasil vivendo sua integração à comunicação de massas, via rádio e agora também via televisão. Ao mesmo tempo em que os mecanismos repressivos da ditadura recrudescem e a brutalidade e a violência se instauram, o clima de prosperidade, parte do discurso oficial do governo, é amplamente veiculado pela mídia.

A mídia cultural que alcançou maior impacto durante o regime militar foi a televisão. Em 1960, o ano em que Jânio Quadros ganhou a presidência, o Brasil tinha menos de 600 mil aparelhos de TV. Em 1986, o ano após o retorno das eleições presidenciais, o total era de 26,5 milhões, um aumento de mais de quarenta vezes, ajudado por termos de instalação favoráveis induzidos pelo governo. O número de estações havia aumentado a uma taxa ainda mais rápida. Em 1964 havia apenas 14, enquanto em 1985, quando o último general deixou a presidência, havia 150. Além disso, uma rede de microondas construída pelo governo ajudou a criar um sistema de dimensão

\footnotetext{
${ }^{5}$ Para uma maior compreensão das transformações culturais que ocorreram no Brasil nos anos 70, podem ser consultados Novaes (2005), Severiano e Mello (1998), Motta (2000 e 2007) e Bahiana (2006a e 2006b).
} 
nacional, o que significava que o governo federal, por meio de seu licenciamento, podia moldar (e moldou) a propriedade da mídia da qual a maioria dos brasileiros obtinha suas notícias e entretenimento (SKIDMORE, 1998, p. 240).

A indústria do entretenimento, em parte também em função do crescimento econômico, conhece um momento de expansão, que se reflete diretamente na produção e no consumo de discos, veiculados primeiramente nos programas de rádio e TV, que começam a formar um público segmentado de acordo com os padrões musicais. Assim como nos países da América do Norte e Europa, o público jovem é o alvo de maior interesse da indústria fonográfica. Os programas musicais ganham destaque também na televisão, consolidando um grupo de artistas nacionais e uma audiência fiel do público jovem. O aumento dos índices de audiência proporcionado pela programação jovem, representada na TV pelos novos cantores e compositores nacionais, leva a outra modificação também na programação das rádios, em especial na Rádio Mundial AM, com o programa comandado pelo radialista Big Boy, que, com suas expressões e gírias amalucadas, constitui um novo personagem, mais próximo do público jovem e em acordo com as músicas veiculadas, que tinham como base os principais lançamentos do hit-parade norte-americano e europeu.

O aparecimento de Big Boy possibilitou um contato entre as rádios e o público jovem, que já começava a ser privilegiado nos programas da televisão. Big Boy, ou melhor, Newton Duarte de Alvarenga, criou um dos primeiros programas voltados a esse público, com enorme audiência. O sucesso no rádio levou à idéia da promoção dos "Bailes da Pesada", eventos que aconteciam no Canecão, cervejaria localizada no bairro de Botafogo, Zona Sul do Rio de Janeiro, aos domingos. Tendo como companheiro Ademir Lemos Inácio, discotecário de grande influência na Zona Sul da cidade, os Bailes da Pesada eram noites dançantes, embaladas pelo som de toca-discos e por jogos de luzes. A programação era constituída por blocos com as novidades do rock e da soul music, entremeadas com as intervenções de Big Boy, já assumindo as funções de DJ que posteriormente seriam a base do funk e do hip-hop.

Os Bailes da Pesada, segundo Vianna (1988), atraíam cerca de cinco mil dançarinos por noite, vindos tanto da Zona Sul como da Zona Norte da cidade. Impossibilitados de continuar na casa e percebendo a adesão da população da Zona Norte, Ademir resolve transferi-los, então, para os clubes da periferia. Essa mudança propiciou a disseminação do estilo soul, o crescimento do número de adeptos aos bailes e o surgimento de dezenas de equipes de som. 
Nos primeiros anos dos anos 70, o Baile da Pesada dominou o mundo 'funky' do Rio de Janeiro, isto é, até que o clube teve uma oferta pra receber Roberto Carlos, o equivalente de Elvis no Brasil, para uma longa temporada, deixando a festa sem casa. Ademir foi contra o juízo convencional e mudou a festa para uma área consideravelmente mais pobre e mais negra na Zona Norte do Rio. A Zona Norte provou ser uma escolha perfeita por várias razões: era predominantemente negra, e também tinha dúzias de lugares grandes, usados regularmente para ensaios de escola de samba e ideais para festas com cinco mil pessoas. Tendo escutado alguns desses novos sons soul no programa de rádio de Big Boy, os jovens negros da Zona Norte agora estavam tendo sua chance de dançar esse som todo final de semana (THAYER, 2006, p. 90-91).

A partir daí, os seguidores dos Bailes da Pesada resolvem constituir suas próprias equipes de som. Oséias Moura dos Santos, Mr. Funky Santos, a quem é atribuída a idéia precursora das equipes, começa com pequenos bailes. O êxito da experiência levou à constituição de bailes que privilegiassem a música negra:

Então nós resolvemos fazer o nosso próprio clube, a nossa própria linha musical, porque até então o Big Boy era assim: ele apresentava um programa na rádio, mas o baile era outro. O baile só tinha conotação black a partir do momento que o Ademir pegava nos pratos. Enquanto o Ademir não pegava nos pratos, não tinha a conotação black do baile. O DJ do Big Boy que é o Peixinho que dava umas incursões fazia umas incursões aqui na nossa área, mas não era aquilo. Então Santos e a Equipe Por do Som foi a primeira festa black, a primeira festa negra, 100\% negra nesse país (Mr. FUNKY SANTOS, 03 jul. 2007).

O próprio Big Boy reconhecia a diferença dos estilos:

Em seus bailes de subúrbio, Big Boy já tinha percebido as particularidades do público arrebanhado por essas equipes de black music. Bastou, para isso, botar nos pratos um disco do Emerson, Lake \& Palmer, sensação do branquíssimo rock progressivo. 'Eles começaram a vaiar, igual nos Estados Unidos', disse à revista Rock, em 1974. 'Eles querem é soul, e mesmo assim James Brown. Não aceitam música branca, mais lenta, sem a bateria marcada' (ESSINGER, 2005, p. 30).

O sucesso de Mr. Funky Santos levou à criação de várias equipes de som, como Black Power, Uma Mente Numa Boa, Célula Negra, Atabaque, Revolução da Mente (alusão ao disco homônimo de James Brown), Cashbox, a Furacão 2000, que existe ainda hoje (em outro formato, mais voltada para o funk), e a Soul Grand Prix, responsável pela conotação política que desembocaria no movimento Black Rio, entre outras que surgiram e acabaram muito rapidamente.

O ritmo soul, que já dominava os bailes, começa a ser incorporado pelas rádios e propicia o surgimento de novos cantores voltados para o estilo. Nesse período, fortemente 
marcado pela repressão política, surgem os festivais de música ${ }^{6}$, promovidos pelas redes de televisão com o apoio, e em alguns casos até mesmo patrocínio, do governo militar.

Os festivais da canção tornaram-se uma ferramenta de propaganda do governo brasileiro, ao apresentarem um clima de alegria, estimulado também pelas campanhas capitaneadas pelo sucesso de Dom \& Ravel "eu te amo meu Brasil”, ou pelos versos que comoviam "90 milhões”, saudando a seleção brasileira, tricampeã mundial em 1970, composto por Miguel Gustavo. Os Festivais Internacionais da Canção (FIC), realizados em sete edições (de 1966 a 1972) no Maracanãzinho, no Rio de Janeiro, tiveram o apoio da Rede Globo $^{7}$, emissora que teve um crescimento vertiginoso a partir do governo militar.

Gradualmente o festival se transformava numa grande janela escancarada para mostrar a felicidade do povo brasileiro. As odiosas vaias de cunho político eram coisa do passado. [...] A liberdade manifesta na assistência do Maracanãzinho era um símbolo vivo, talvez até mais valioso e eficaz que as ações da AERP (Assessoria Especial de Relações Públicas) promovidas no governo anterior. Claro, liberdade desde que não ofendesse a família brasileira.

A TV Globo tinha plena consciência do significado do FIC para o governo, ao mostrar no exterior a imagem do povo brasileiro cantando e espantando seus males. Tanto que, mesmo reconhecendo o prejuízo anual desde 1967, quando investira 140 mil cruzeiros contra 240 mil da Secretaria de Turismo, continuava investindo, passando agora a arcar com $3 / 4$ partes dos custos contra $1 / 4$ da Secretaria, para quem também as despesas se justificavam (MELLO, 2003, p. 368-369).

A realização do V FIC, em 1970, precedido pela conquista do tricampeonato mundial no futebol, trazia um clima de euforia. Trazia também entre os concorrentes uma forte influência da soul music, já demonstrada na apresentação da primeira concorrente da noite, Abolição 1860-1980, em 15 de outubro.

Apesar da objeção do governo e dos críticos, o V Festival Internacional da Canção em 1970 provou ser um ano que abriu o caminho para vários artistas brasileiros do estilo soul. O grupo de Dom Salvador tocou com Maria Alcina e Luiz Antonio a composição de Salvador 'Abolição 1860-1980'. Erlon Chaves e Banda Veneno tocaram o tórrido 'Eu Também Quero Mocotó', com uma apresentação controvertida onde duas dançarinas louras beijaram abundantemente o negro líder da banda. Esse ousado ato ofendeu a

\footnotetext{
${ }^{6}$ Nesse período, a Record contratou Solano Ribeiro, que realizara o I Festival de Música Popular Brasileira na Excelsior em 1965 e trouxe a estrutura de competição dos festivais para a Record. Ribeiro se inspirou no modelo italiano dos festivais de San Remo. Após o I Festival de Música Popular Brasileira, seguiram-se outros, começando o período da Era dos Festivais, que durou até 1972, um dos momentos mais expressivos de produção musical. [...] O sucesso artístico e de público do empreendimento da Record levou a Globo a realizar os Festivais Internacionais da Canção, que duraram até o início dos anos 70, atraindo grandes nomes da música brasileira e estrangeira (ROCHA, 2007, p. 142).

${ }^{7}$ Apenas o primeiro deles (I FIC), realizado em 1966, foi transmitido pela TV Rio.
} 
sensibilidade social e racial da ditadura e resultou em uma curta estada na cadeia para Chaves, repleta com interrogatório e tortura.

Toni Tornado, com o grupo vocal negro Trio Ternura, fez seu debut com uma poderosa balada estilo Solomon Burke 'B.R.3', escrita por Antonio Adolfo. Com mais de $1.80 \mathrm{~m}$ de altura, vestido nas últimas modas de Harlem, e desfilando um afro, Tornado e sua apresentação tiveram um impacto enorme no público brasileiro. Com um poderoso vocal inspirado no soul e a imagem para combinar, ele desafiou a imagem tradicional do cantor negro brasileiro. Toni havia retornado recentemente de Nova Iorque, onde estava morando, e onde absorveu as culturas radicais e políticas do Harlem nos anos 60. Sua apresentação no festival resultou em dois LPs, vários singles, e a atenção persistente da polícia militar por ter usado sua identidade negra na sua manga colorida de poliéster. Ele foi falsamente acusado de ter começado uma célula brasileira dos Black Panthers e foi perturbado rotineiramente por seu relacionamento com uma popular atriz branca (THAYER, 2006, p. 9293).

Alguns dias após a apresentação, Toni Tornado e mais um grupo de 42 jornalistas foram recebidos no Palácio das Laranjeiras pelo presidente Médici, que manifestou o desejo de que BR-3 levasse o Brasil também à conquista do tricampeonato na música. Na final internacional, acontecida no domingo, 25 de outubro, no entanto, nem BR-3, nem a performance enlouquecida de Erlon Chaves encerrando o festival rodeado de bailarinas brancas semi-despidas que o beijavam conseguiram os prêmios almejados pelo presidente. Ao contrário.

A noitada foi mais longa que o esperado: teve show de Ray Conniff, Jair Rodrigues, Spanky Wilson e Erlon Chaves, mas nem Toni, gritando 'Deus!' e plantando bananeira, nem Erlon foram os destaques que prometiam. $\mathrm{Ou}$ melhor, foram sim, mas num outro sentido.

As performances anteriores de um e de outro tinham causado tal rebuliço que agora simbolizavam uma ameaça: a do homem negro podendo invadir a família branca brasileira e fazer um estrago. Os militares deram mostras de temer que Toni Tornado pudesse tornar-se um novo líder negro, a exemplo do que acontecia nos Estados Unidos com os violentos Panteras Negras. A frivolidade crescente do competente maestro Erlon Chaves, ocasionalmente um jurado debochado no programa de calouros de Flávio Cavalcanti e naquele momento namorando Vera Fischer, poderia mexer com o conservadorismo da família de classe média brasileira. Era um terreno perigoso que nenhum dos dois conhecia (MELLO, 2003, p. 384).

Erlon foi preso imediatamente após sua saída do palco, acusado de atentado à moral. Solto pela intervenção de Flávio Cavalcanti, o maestro, passados alguns dias, foi preso novamente e proibido de exercer suas atividades profissionais em todo o território nacional pelo prazo de 30 dias. A partir daí, sua carreira, até então promissora, entrou em declínio. Seriamente abalado, Chaves voltou apenas a compor arranjos e morreu de enfarto em 1974, aos 40 anos.

A carreira de Toni Tornado nem bem começara, também foi alvo de várias 
arbitrariedades. O colunista social Ibrahim Sued criou um embuste sugerindo que a música BR-3 fazia apologia às drogas, forma de divulgar o livro escrito por seu amigo General Jaime Graça, denominado Tóxico. ${ }^{8} \mathrm{O}$ romance com a atriz Arlete Salles, branca, rendeu insultos a ele e restrições a Arlete na emissora de TV em que trabalhava. A perseguição a Tornado se intensificou, principalmente em função da sua proximidade com o público dos bailes black, levando-o ao exílio.

Se Toni Tornado fosse branco, talvez tivesse sido diferente. Como não era bem visto pelos militares e ainda exercia uma atividade de pregação social em favor dos negros nos bailes black da periferia, um certo dia, em 1972, 'os homens' entraram derrubando a porta de seu apartamento. Foi conduzido para a praça $\mathrm{XV}$, levado a Brasília e depois convidado a sair do país (MELLO, 2003, p. 390).

Mello (2003, p. 390) afirma que o "V FIC deixou um rastro de racismo, uma marca de preconceito contra artistas da raça negra”. No entanto, se, por um lado, a repressão nos bastidores aconteceu com tanta força, por outro, o que foi visto por milhares de negros foi outra. O V FIC foi uma demonstração do poderio do negro, de seu talento e orgulho da raça. A revolução da black music no País já estava em marcha, num processo que parecia irreversível.

A soul music conquista a periferia; um crescente mercado fonográfico e de moda começa a surgir em função do movimento. A força maior do movimento black power no Brasil se traduz no aparecimento daquele que é considerado o James Brown brasileiro Gerson King Combo -, com as músicas Mandamentos Black e O Rei Morreu (Viva o Rei). O discurso presente nas músicas de King Combo, principalmente em Mandamentos Black, foi alvo da repressão policial, acusado de "levantar a bandeira negra”. Como ele explica:

Por levantar bandeira negra que supostamente era levantar os negros, incitar a se revoltar. Em um programa de Haroldo de Andrade, famoso aqui, radialista. Ele fazia aquela mesa [...] - 'olha, esse Gerson ele está levantando a bandeira negra’. - o povo lá, Federal (a polícia) ouvia. Eu estava em São Paulo quando a minha falecida esposa me ligou: - 'olha tão falando que você tá não sei o quê'. Tinha que ser preso. Não deu outra (GERSON KING COMBO, 02 jul. 2007).

De acordo com o músico, sua prisão não durou muito tempo. O cantor atribui ao fato uma dimensão menos política e mais pessoal:

\footnotetext{
${ }^{8}$ De acordo com Mello (2003, p. 388), ”na sua capa vermelha, o título lembrava uma carreira de cocaína e nas primeiras páginas sugeria que a música "BR-3” era um hino ao toxicômano com a substituição dos versos de Tibério no início da música: "Há uma seringa/que vem do céu, cruzando o braço/ e uma agulha feita em aço/ pra espetar outra vez".
} 
Mas ele queria audiência só porque eu estava na mídia. Ele não me ajudou em nada. Não tocou meu disco, não tocou nada e ainda ficava me malhando. Quer dizer, quer um pouco mais de audiência, mas a gente vai dar assim mesmo. Aí eu tirei aquela acareação na Polícia Federal, em 70 mais ou menos, eu tirei meio rindo, meio assim jocosamente porque eu achava aquilo uma brincadeira que estavam fazendo comigo: - 'esse negrão aí tá levantando bandeira de nada’ (GERSON KING COMBO, 02 jul. 2007).

No entanto, mesmo afirmando que não existia uma conotação política explícita, Combo reconhece o poder do enunciado:

Resumindo, eu juntei a periferia num grito dizendo que o negro é lindo, porque para mim [...] nos EUA eu via muito a discriminação era muito brava, não podia beber água, eu tinha horror de ver aquilo, mas cada um com a sua cultura. Nós imputamos aqui no Rio, no Brasil, uma cultura negra que não ferisse muito, quer dizer, ou deixava o negro mais com [...] é assim 'eu sou gente também’ (GERSON KING COMBO, 2 jul. 2007).

O discurso de valorização dos negros, já amplamente disseminado em nosso país a partir do Movimento Pelos Direitos Civis, pelo movimento Soul e pelo discurso radical dos Panteras Negras e Black Power nos Estados Unidos, começa a circular com intensidade na produção musical e na incorporação dos estilos de cabelos e no vestir. Uma perspectiva mais politizada toma forma a partir do grupo intitulado Soul Grand Prix, a equipe de som responsável pela constituição de um dos mais importantes eventos da black music no Rio de Janeiro - a Noite do Shaft -, no Renascença Clube ${ }^{9}$, na Zona Norte.

Esse grupo, que permanecerá coeso até por volta de 1975, será posteriormente identificado por seus participantes como 'a geração que revolucionou o Renascença’. Vários de seus principais líderes já eram freqüentadores do Clube, assíduos e entusiastas participantes das rodas de samba. Herdeiros e, simultaneamente, críticos da tradição construída ao longo da história do Renascença, eles querem produzir uma síntese que faça do clube um espaço de vivência e sociabilidade de jovens negros. Vindos da classe média, alguns deles universitários, com acesso a espaços sociais e de lazer da classe média branca da Zona Sul, vão, aos poucos, construir um projeto cultural e político típico de vanguardas militantes: querem atuar entre os jovens negros, querem contribuir para a criação de uma consciência negra e a constituição de um movimento negro (GIACOMINI, 2006, p. 190).

Entre esses jovens estava o estudante de engenharia Asfilófilo de Oliveira Filho, que, em breve, passaria a ser conhecido como Dom Filó. Ele teve a ideia de usar a noite de domingo, sua incumbência, para realizar um baile para os jovens, tendo a música norte-

\footnotetext{
${ }^{9}$ A própria história do Renascença Clube é um fator distintivo na história. O Renascença foi fundado em 17 de fevereiro de 1951, contando com um núcleo de 29 sociofundadores, todos negros e bem-sucedidos profissionalmente.
} 
americana como base.

Com a ideia em mente, Dom Filó e a diretoria do Renascença visitam o baile de Mister Funky Santos no Astoria: "Eram 1.500 pessoas e o Santos fazendo o som com tudo escuro, uma luz só”, recorda-se. "Vimos que poderíamos fazer a mesma coisa no Renascença, mas com um diferencial: a consciência negra” (ESSINGER, 2005, p. 19). O traço político do movimento já estava decidido bem antes da ação propriamente dita. Ele vem da participação de Dom Filó e outros integrantes do Renascença, em discussões acerca da questão negra e da organização do movimento negro.

Por que a coisa começa a ser definida politicamente? Porque eu antes de ser, de entrar no contexto do Black Rio do Renascença, nós freqüentávamos as discussões políticas. Não existia o movimento negro, nenhuma entidade que representava o movimento negro naquela época, mas os artistas se reuniam discutindo a questão racial e alguns setores se reuniam independentes, na época, na universidade Cândido Mendes. Na Cândido Mendes eles se reuniam aqui no centro Afro-Asiático discutindo a necessidade de ter uma representatividade, ter uma instituição. E paralelo, na zona sul, onde tinha a Siqueira Campos, onde existia o teatro Opinião, ali era o celeiro do samba de raiz na zona sul, todas as segundas-feiras em frente à Adega Pérola se reuniam os artistas para discutir a questão racial e isso fez com que houvesse um sincronismo e todos foram para a universidade discutir. Mas só que alguns como eu, éramos muito elétricos. Nós não gostávamos muito da discussão. Desse papo a gente já estava cansado. Nosso negócio era outro. Então se definiu no movimento negro duas vertentes: uma vertente é aquela apaixonada pela oratória e aquela outra era apaixonada pelas armas. Eu era pelas armas. Não necessariamente armas contundentes, outras armas. Por exemplo, como é que se definia isso: você tinha um grupo que era a favor da luta dos povos, luta da libertação dos povos africanos que seguiam Samora Machel, Agostinho Neto, Amílcar Cabral. Por outro lado tinha outro grupo que era a favor dos Black Panters, direitos civis americanos que seguiam Malcolm X, Martin Luther King (DOM FILÓ, 3 jul. 2007).

Seguindo os passos do movimento americano e flertando com as ações do grupo Black Panthers, a equipe definiu uma estratégia para os bailes do Renascença.

Agora como colocar na massa as informações políticas, esse era o segredo que começa a partir do Renascença porque quando a gente vai para o baile do Renascença o nome da festa já era uma questão política, chamava-se noite do Shaft ${ }^{10}$, em função daquele ator, daquele detetive negro que era 0 nosso referencial. Porque ele era um grande detetive que era o mocinho da parada. Aquilo ali virou noite do Shaft. Em contrapartida nós pegávamos as revistas que chegavam tipo Ebony e mais outra que eu não me lembro agora o nome. Nós fotografávamos essas revistas, extraíamos ali os artistas negros,

\footnotetext{
${ }^{10}$ O nome refere-se ao filme Shaft, de 1971. Dirigido por Gordon Parks e estrelado por Richard Roundtree, o filme notabilizou-se por lançar um herói negro, quase um similar de James Bond, porém carregado do linguajar do gueto, das roupas e cabelo black power. Shaft pode ser considerado um dos primeiros filmes que inaugura a vertente chamada blaxploitation (filmes feitos por negros e para negros) e que teve um grande orçamento. A trilha sonora, composta por Isaac Hayes, um dos expoentes do movimento soul, ganhou o Oscar.
} 
colocávamos em slides e projetávamos nas paredes do clube que era uma parede grande ao ar livre, isso usando quatro, cinco, seis projetores Ektagraphic que eram automáticos. Era uma programação visual muito igual porque você soltava cada um num tempo. Então havia lá várias imagens que geralmente eram imagens desses artistas negros junto com a comunidade que era fotografada num dia e aparecia no outro. Naquela época a gente já fazia comunicação que hoje a gente faz aí nas nossas ações, quer dizer, 'autoestima' pura. As pessoas querem se ver e com isso daí a gente conseguiu atrair a comunidade que se via. Então aquele cara que vinha com um visual não queria voltar no outro dia com o mesmo visual. Ele queria estar mais bonito ainda. Ele ia usar um adereço a mais, ele curtia isso. Mesmo não tendo recurso ele sempre dava um toque diferente. Isso se falar nos homens. As mulheres então, maravilha. Isso daí fez com que a auto-estima crescesse dentro dos bailes Black (DOM FILÓ, 3 jul. 2007).

Entremeados aos slides dos astros e frequentadores, Dom Filó interrompia a discotecagem e falava algumas mensagens, que também eram exibidas em slides.

De uma certa forma ele foi o pai dos $\mathrm{MCs}^{11}$ no Rio de Janeiro. 'O seu cabelo cresce dia-a-dia, mas o mais importante é o que está debaixo desse cabelo. O que você está pensando do futuro?', mandava. Falando de jovem para jovem, Filó abordava brevemente temas como estudo, família, droga e violência. E pregava: 'Nós temos que nos organizar como negros, senão nós não vamos chegar lá' (ESSINGER, 2005, p. 22-23).

A questão da autoestima levantada nas noites do Shaft gerou uma série de outros estímulos. Em alguns bailes, havia premiação para os blacks mais bonitos, para os que se parecessem com o músico Isaac Hayes, para os melhores dançarinos. Nos panfletos, mensagens como "leve um analfabeto ao MOBRAL" (da Equipe Black Power), ou mensagens como “o amor exige presença. Sem sua presença não haverá amor” (festa de lançamento do $2^{\circ}$ LP do DJ Luizinho e 3 Encontro Black Rio) logo se tornaram marcas distintivas dos bailes black.

A mudança para outros espaços, como o Clube Maxwell e o Cascadura Tênis Clube, acarretou uma mudança e aumento do público nos bailes; em contrapartida, a mensagem política dos slides chocou parte da audiência. "Aí você tinha que aparecer com alternativas. Foi quando eu criei a Soul Grand Prix, soul em alta velocidade”, conta Dom Filó, explicando: era Soul Grand Prix porque ele entremeava os slides black com cenas dos pilotos de Fórmula 1: "Era a única forma de burlar a questão da censura” (ESSINGER, 2005, p. 23). O sucesso dos bailes da Soul Grand Prix, com suas peculiaridades, foi o estopim para a criação do que a imprensa carioca chamaria Movimento Black Rio.

\footnotetext{
${ }^{11}$ MCs ou Masters of Cerimony é um termo usado para definir os cantores de rap, que a princípio usavam o microfone para “fazer seu discurso" (VIANNA, 1988).
} 
Os bailes da Soul Grand Prix passaram a ter uma pretensão didática, 'fazendo uma espécie de introdução à cultura negra por fonte que o pessoal já conhece como a música e os esportes’ (Jornal de Música, n̊ 30:4). Enquanto o público estava dançando, eram projetados slides com cenas de filmes como Wattstax (semidocumentário de um festival norte-americano de música negra), Shaft (ficção bastante popular no início da década de 70, com atores negros nos papéis principais), além de retratos de músicos e esportistas negros nacionais ou internacionais. Os dançarinos que acompanhavam a Soul Grand Prix, e também a equipe Black Power, criaram um estilo de se vestir que mesclava as várias informações visuais que estavam recebendo, incluindo capas de discos. Foi o período dos cabelos afro, dos sapatos conhecidos como pisantes (solas altas e multicoloridas), das calças de boca estreita, das danças à James Brown, tudo mais ou menos vinculado à expressão 'Black is beautiful'. Aliás, James Brown era o artista mais tocado nos bailes. Suas músicas, principalmente 'Sex Machine', 'Soul Power', 'Get on the Good Foot', lotavam todas as pistas de dança (VIANNA, 1988, p. 27).

Os bailes começaram a reunir um público que girava entre 5 mil e 15 mil pessoas por noite. Com um movimento tão grande, vivendo um período de repressão política, pois eram os anos 70, a polícia, certamente, vigiava as atividades das equipes, como na festa de lançamento do primeiro disco da Soul Grand Prix, como relata Filó:

Veio a PM com mais de 600 homens querendo quebrar tudo, e eu só tinha uma alternativa: o microfone. Fui iluminado e falei: 'A PM está aqui para nos proteger, até porque eles vêm para mostrar a segurança, não a violência'. Foi a primeira grande demonstração de força daquela garotada negra do subúrbio em sua busca por diversão e identidade. Um ano depois ela ganharia nome: Black Rio (ESSINGER, 2005, p. 29).

Enquanto os órgãos de repressão e controle vigiavam os bailes, a mídia começa a perceber que ali se constituía um movimento, que também se criava um grande mercado consumidor de discos, roupas, acessórios. O grande destaque surge a partir da publicação da matéria "Black Rio - O Orgulho (Importado) de Ser Negro no Brasil”, publicado pela jornalista Lena Frias, na edição do dia 17 de julho de 1976, no Caderno B do Jornal do Brasil. A reportagem, de quatro páginas, atribui, finalmente, aos bailes black uma conotação de movimento cultural, e que já se disseminava pelo País afora.

Uma cidade de cultura própria desenvolve-se dentro do Rio. Uma cidade que cresce e assume características muito específicas. Cidade que o Rio, de modo geral, desconhece ou ignora. Ou porque o Rio só sabe reconhecer os uniformes e os clichês, as gírias e os modismos da Zona Sul; ou porque prefere ignorar ou minimizar essa cidade absolutamente singular e destacada, classificando-a no arquivo descompromissado do modismo; ou porque considera mais prudente ignorá-la na sua inquietante realidade. [...] Uma população cujos olhos e cujos interesses voltam-se para modelos nada brasileiros. População que forma uma cidade móvel, cujo centro se desloca permanentemente - ora está em Colégio, onde fica o clube Coleginho, 
considerado um dos primeiros templos do soul, ora em Irajá, ora em Marechal Hermes ou em Rocha Miranda, ora em Nilópolis ou na Pavuna, cujos pontos de encontro e de decisão são as calçadas do Grande Rio, em Madureira ou no Calçadão em Caxias; em Vilar dos Teles ou na Rua Sete de Setembro, no Centro do Rio.

Uma cidade cujos habitantes se intitulam a si mesmos de blacks ou de browns; cujo hino é uma canção de James Brown ou uma música dos Blackbyrds; cuja bíblia é Wattstax, a contrapartida negra de Woodstock; cuja linguagem incorporou palavras como brother e white; cuja bandeira traz estampada a figura de James Brown ou de Ruffus Thomas, de Marva Whitney ou Lin Collins; cujo lema é I am somebody; cujo modelo é o negro americano, cujos gestos copiam, embora sobre a cópia já se criem originalidades. Uma população que não bebe nem usa drogas, que evita cuidadosamente conflitos e que se reúne nos finais de semana em bailes por todo o Grande Rio.

É o soul power, fenômeno sociológico dos mais instigantes já registrados no país (FRIAS, 17 jul. 1976, p. 1). (Grifo no original).

A importância da matéria de Lena Frias reside, entre outros fatores, no fato de ter sido a primeira, de uma série de outras, que discorreriam em apoio ou não do movimento Black, e também de perceber que ali se formava um movimento social, até certo ponto itinerante (pois os bailes mudavam a cada final de semana), mas fortemente coeso a partir a criação de uma identidade coletiva. O trabalho de Frias causou grande repercussão, não apenas entre a comunidade negra, mas gerou uma série de outras matérias, nem todas favoráveis ao movimento. A reação entre a comunidade black também foi dividida. Vianna (1988) comenta:

Hoje, as pessoas que viveram o ‘Black Rio’ não guardam boas recordações dessa matéria. Paulão, dono e discotecário da equipe Black Power, afirma: Que eu saiba, foi o Jornal do Brasil que inventou o nome Black Rio. Eu nem sei se o meu nome estava ali naquela matéria. Eu nem sei quem é a Lena Frias. Mas o nome da minha equipe era muito forte e, de carona nessa história de Black Rio, eu fui parar no DOPS (VIANNA, 1988, p. 27).

A reação do Departamento de Ordem Política e Social (DOPS) também se estendeu a Dom Filó e a outros integrantes da Soul Grand Prix, que foram presos em diversas ocasiões, inclusive acusados de receber financiamento do movimento Black Panther.

O movimento Black Rio pode ser considerado o divisor de águas, pois foi aquele que teve a maior repercussão na mídia, conseguindo, assim, uma divulgação para um movimento que já acontecia em muitas cidades do País. As festas começam a chamar a atenção, não apenas pela quantidade de pessoas que ali se reuniam, mas também pela peculiaridade de suas características. Uma nova identidade começava a se delinear a partir do movimento black, que se disseminava por todo o País. Logo, as discussões provocadas pela mídia giravam em torno da autenticidade, ou não, desse movimento brasileiro, mas com raízes estrangeiras. 
Entidades ligadas ao movimento negro, na época, apoiaram o movimento, entendido como uma forma de superação do racismo. Nas palavras de um dos diretores do Instituto de Pesquisa das Culturas Negras (IPCN), citado por Vianna:

É claro que dançar soul e usar roupas, penteados e cumprimentos próprios não resolve, por si, o problema básico de ninguém. Mas pode proporcionar a necessária emulação - partir da recriação da identidade negra perdida com a Diáspora Africana e o subseqüente massacre escravista e racista - para que se unam e, juntos, superem suas dificuldades (Jornal da Músicaß3n agosto de 1977: 16)' (VIANNA, 1988, p. 28).

O soul, na visão do movimento negro, deixava de ser apenas uma oportunidade de diversão e passava a ser reconhecido como um movimento em busca da igualdade racial. Vianna (1988) aponta essa percepção a partir do comentário publicado na coluna “AfroLatino-América” do jornal Versus, em 1978:

'Black Rio, Black São Paulo, Black Porto e até Black Uai! Primeiro a descoberta da beleza negra. O entusiasmo de também poder ser black. A vontade de lutar como o negro norte-americano, em busca da libertação do espírito negro, através do Soul (Versus, maio/junho de 1978:42)' (VIANNA, 1988, p. 28).

Diversas ações dos movimentos negros incorporavam a linguagem do soul, como forma de cooptação, como a apresentação do Wattstax, na Cinemateca do Museu de Arte Moderna do Rio (MAM), para comemorar o primeiro aniversário do Instituto de Pesquisa das Culturas Negras (IPCN), como narra a matéria de Frias (1976):

Aberta a bilheteria, rapidamente os 220 lugares ficam ocupados e, poucos minutos após, quase 320 pessoas comprimem-se na sala da Cinemateca. Lá embaixo, no pátio, outros tantos ainda tentam entrar. Antes de iniciar a sessão, um membro do IPCN explica a razão da festa: ‘É a melhor forma que nós encontramos de comemorar o primeiro aniversário do Instituto de Pesquisa das Culturas Negras. Não tem bolo nem vela pra apagar, mas tem um convite para vocês: vamos dar continuidade ao nosso trabalho, a partir da semana que vem com reuniões' (FRIAS, 1976, p. 4).

A escolha do filme justifica-se com o depoimento da jornalista na sequência:

O público repete as palavras, as frases, embora o sentido lhes possa até ser desconhecido. E quando o reverendo Jesse Jackson aparece na tela conclamando os negros americanos à profissão de fé na própria raça, o cinema, a exemplo do que acontece em todas as exibições do Wattstax no Grande Rio, repete com ele as palavras que fazem chorar um jovem negro de 16 anos, Roberto, estafeta, que está a meu lado, espremido no corredor da cinemateca: 'I am somebody'. Jessie Jackson fala na tela, com o punho erguido, braço dobrado para dentro, a multidão no estádio de Los Angeles 
repete gesto e palavras. Na pequena multidão reunida no MAM, como nas grandes multidões reunidas nos ginásios da Zona Norte e Baixada, alguns punhos também repetem o movimento, e todo mundo dizia em coro, uns mais alto, outros quase sussurrando: 'I am somebody' (FRIAS, 1976, p. 4).

O produtor musical André Midani, fascinado pelos bailes (e tendo músicos contratados para sua gravadora), incentivou a cobertura pela mídia, ampliando a dimensão do movimento black. Em 1978, a revista Veja publicou uma reportagem abordando os debates entre "Velhas Guardas versus Jovens Guardas", ou seja, entre a tradição do samba e a inovação da soul music. A matéria trouxe para o produtor uma situação inusitada:

Algum tempo depois da matéria da Veja, Aloysio de Oliveira, voltando de Brasília me advertiu sobre rumores de um processo contra mim, visando a me expulsar do país. [...] Por que ser expulso? Para quê? Justo naquele momento, quando a ditadura já estava se amansando... A alegação, que parecia de um filme de ficção, era que eu recebia dinheiro, através da Warner norte-americana, proveniente dos contestadores movimentos black americanos, liderados pelo Quincy Jones, para financiar a revolução e a insurgência dos negros nas favelas brasileiras. E que as reportagens sobre os bailes na Zona Norte eram nada menos que o sinal de partida dessa operação, e faziam parte de uma estratégia de desestabilização. Desde aquela época os militares já se mostravam preocupados com essa eventualidade, por entender que uma guerrilha com sede nas favelas representava um perigo muito complicado de ser resolvido (MIDANI, 2008, p. 181).

O temor dos militares, mesmo já em tempos de abertura política, não se mostrou infundado, pois os fenômenos culturais, ainda que aparentemente desconectados da ação política, revelam estruturas de poder e conflito, que muitas vezes podem interferir na ordem social vigente.

Mas os fenômenos culturais também estão implicados em relações de poder e conflito. As ações e manifestações verbais do dia-a-dia, assim como fenômenos mais elaborados, tais como rituais, festivais e obras de arte, são sempre produzidos ou realizados em circunstâncias sócio-históricas particulares, por indivíduos específicos providos de certos recursos e possuidores de diferentes graus de poder e autoridade; e estes fenômenos significativos, uma vez produzidos ou realizados, circulam, são recebidos, percebidos e interpretados por outros indivíduos situados em circunstâncias sócio-históricas particulares, utilizando determinados recursos para captar o sentido dos fenômenos em questão. Entendidos dessa maneira, os fenômenos culturais podem ser vistos como expressão das relações de poder, servindo, em circunstâncias específicas, para manter ou romper relações de poder e estando sujeitos a múltiplas, talvez divergentes e conflitivas, interpretações pelos indivíduos que os recebem e percebem no curso de suas vidas cotidianas (THOMPSON, 2002, p. 179-180). 
Mesmo com toda a mobilização da comunidade negra, o movimento Black Rio começa a dar sinais de fraqueza a partir da constituição de outro fenômeno musical: a discomusic. Com uma divulgação maciça, tendo uma novela de audiência incontestável para alardear o movimento - Dancin'Days -, ao lado do filme Os embalos de Sábado à Noite, e do combate implícito nos programas humorísticos que ironizavam os blacks, rapidamente os bailes perdem a conotação de exclusividade black, e o ritmo soul começa a perder espaço para a discoteca. Tal fenômeno acontece simultaneamente nos Estados Unidos. A era disco teve uma duração curtíssima, mas foi o suficiente para desarticular o movimento black.

Nos anos 1960-70, a situação do negro na sociedade brasileira não mudara substancialmente. [...] O negro sintetiza a tensão entre a sua situação de raça e a situação de classe. Nos anos ditatoriais a determinação de classe se fortalecerá. Os espaços para a ação política institucional serão praticamente extintos. O regime militar censurou toda e qualquer manifestação de caráter anti-racial e, inclusive, omitiu a rubrica raça no censo de 1970. Os militares oficializaram a ideologia da democracia racial e a transformaram em peça de marketing no exterior. A militância que ousou desafiar o mito da democracia racial foi acusada de "antibrasileiros", "racistas", ou imitadores baratos dos ativistas americanos pelos direitos civis" (SKIDMORE, 1994: 165). A luta racial adquiriu ares de antipatriotismo. Com efeito, a forma corriqueira de negar a existência do racismo e de todas as suas conseqüências é simplesmente fazer de conta que o problema não existe (SILVA, 2004.).

Mesmo desaparecendo aos poucos do cenário urbano, o movimento Black-Rio foi uma poderosa influência para diversos movimentos em todo o País. O ideário do orgulho negro se espalhou em diversas cidades, como é o caso de Belo Horizonte.

O Movimento Soul em Belo Horizonte: a afirmação do orgulho e da identidade negra no espaço urbano 


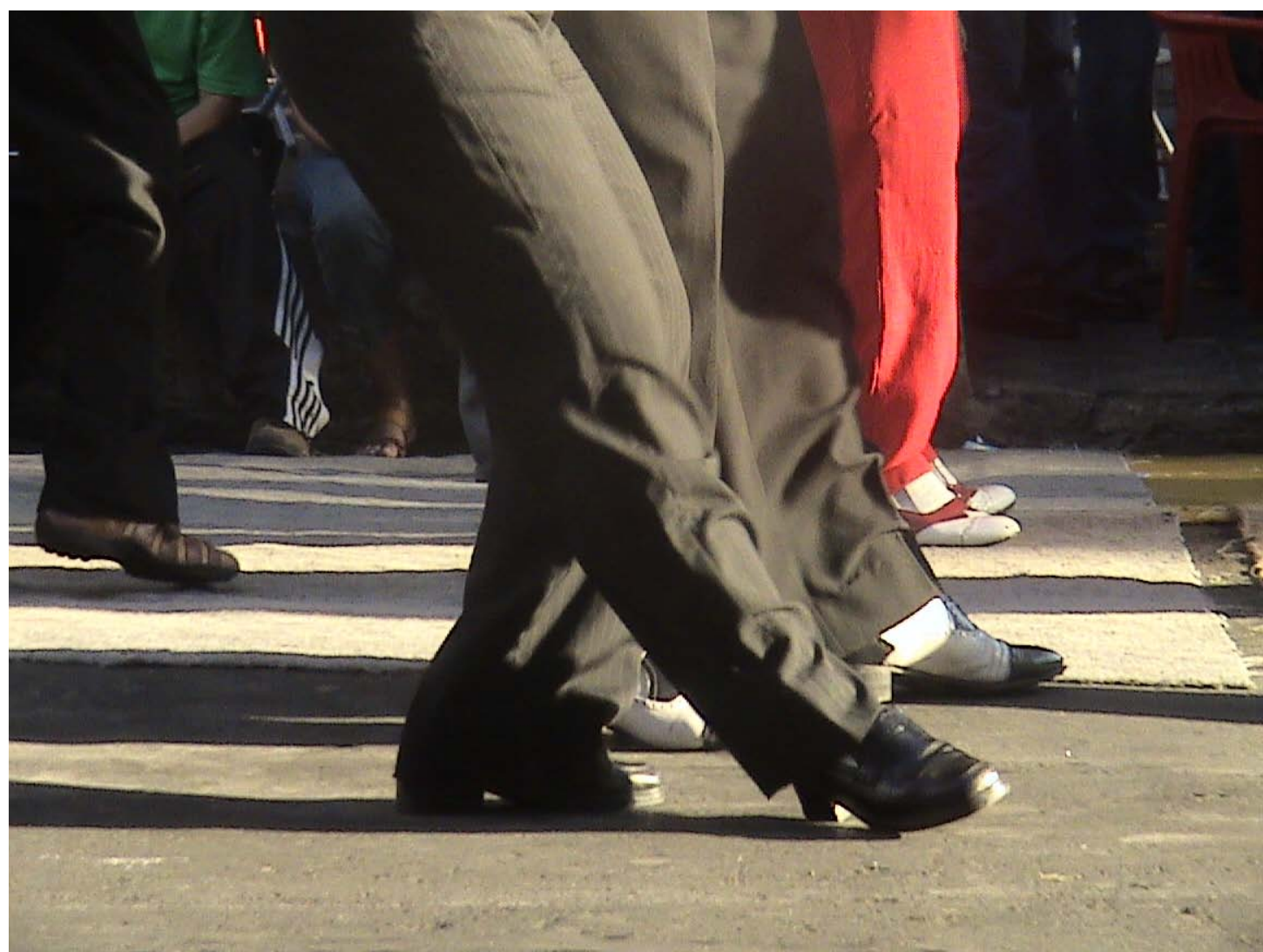

Assim como no Rio de Janeiro, o movimento soul começa em Belo Horizonte a partir da influência do rádio, no caso, da rádio Cultura AM. E, assim como o Big Boy foi o radialista que trouxe a linguagem jovem para o rádio no Rio, em Belo Horizonte, essa transição foi encabeçada pelo radialista Geraldo Ferreira de Souza, o Geraldão.

O rádio, nessa época, era um rádio comportado, o rádio brasileiro passava por uma fase interessante, eu acho porque havia um rompimento político violento, o movimento de 64, e que o rádio foi assim, a primeira grande vítima da ditadura. Então o rádio teve que procurar uma acomodação. Esse foi o período, já pós 64, e o rádio ficou aquela coisa monótona, a música, as novelas já tinham acabado e o seu poder foi sumindo. Esse era o cenário da época. Em compensação lá em 67, 66 por aí já com os Beatles, uma revolução musical, uma coisa, o rádio foi mudando, foi segmentando, foi procurando um caminho. Belo Horizonte tinha um rádio maravilhoso, sempre teve, mas era um rádio muito comportado havia assim um comportamento geral, aquele rádio certinho. Tinha muito rádio musical, eram locutores de vozes aveludadas com aquela programação que eu sempre fui contra. Então era aquele rádio 'senhoras e senhores' e tal, voz impostada (GERALDÃO, 15 jun. 2007).

A entrada da soul music na programação da Cultura AM se deu em virtude do seu sucesso internacional.

Nos EUA aflorava um movimento já de assentamento da qualidade da música negra. A música negra, nos EUA, assumiu um patamar nessa época de uma qualidade fantástica a mercê da cultura negra dos EUA que já, em 
meados dos anos 60, já tinha, já se falava do Ottis Reding e outros do movimento Soul americano, de uma qualidade inquestionável. E esse movimento, ele deu uma sacudida tão grande na periferia de Belo Horizonte porque a Soul Music atingia exatamente uma faixa pobre que não tinha acesso às tardes do Minas Tênis Clube e era uma música de qualidade e uma cidade também muito racista, Belo Horizonte sempre foi uma cidade impiedosa com o negro. O negro aqui além de ter uma cultura ele tem que brigar pelo seu espaço e mesmo assim é muito difícil. (GERALDÃO, 15 jun. 2007).

Muito distantes da elite que frequentava os clubes da zona sul, os primeiros bailes soul acontecem primeiro, timidamente, nas casas da periferia de Belo Horizonte, embalados pelos Ritmos da Noite ${ }^{12}$, da Cultura AM:

Então começaram aqui em Belo Horizonte as chamadas equipes de som, isso que eu acho que era fantástico, eram jovens de periferia que montavam sua caixinha de som, seu amplificador, na época dos tapes decks, e nas garagens faziam os bailes. A trilha sonora era da Rádio Cultura. Eu sabia por causa da frequiência com que eles corriam à rádio e eu dava toda a informação da música e tal, aí foi crescendo esse movimento. O movimento cresceu tanto que dentro da Rádio Cultura eu criei um marketing especial para atendê-los, ou seja, muitos bailes eu divulgava gratuitamente só pelo prazer do lazer, às vezes era até mal entendido pelo dono da rádio, mas era um movimento que eu sempre tratava com carinho e eles começaram a alugar quadras no Renascença ${ }^{13}$, não sei aonde, na igreja tal, isso foi tomando conta de Belo Horizonte, era o lazer do pobre, era uma coisa sadia (GERALDÃO, 15 jun. 2007).

Dos arredores da cidade, os bailes encontraram no Centro de Belo Horizonte o local ideal para o encontro dos blacks, que vinham dos pontos mais distantes da cidade. $\mathrm{O}$ centro era ideal, pois não havia necessidade de mais de uma condução e todos os ônibus circulavam por lá. O mais conhecido, considerado por todos os envolvidos no movimento como o principal baile era o Máscara Negra, localizado no primeiro andar de um prédio na Rua Curitiba, 482.

Diversos bailes aconteciam no entorno do centro, principalmente nos bairros Carlos Prates (Tremedal, Asteka, Orion, Esparta), no bairro Renascença, em diversos outros bairros. $\mathrm{O}$ advento dos bailes possibilitou a criação também de diversas equipes de som e de grupos de dança. Entre eles Mister Sam Jazz, África Soul, Sonimegion, Ali Babáticos, Stéreo Gladson, Soul Grand Funk, Stéreo Record Som, BlackMinas, Renegados do Funk, Jazz Summer, Woodstock, Brother Soul e BH Soul.

No entanto, a força maior dos bailes, citados por todos os entrevistados que

\footnotetext{
${ }^{12}$ Ritmos da Noite era o nome da programação veiculada pela rádio Cultura na faixa das 22h00, especialmente focada em lançamentos, e que tinha grande audiência.

${ }^{13} \mathrm{O}$ entrevistado refere-se ao bairro Renascença, na região pericentral de Belo Horizonte.
} 
participaram do movimento, residia nos bailes do Máscara Negra e da União Síria, ambos na área central da cidade. Por serem tão frequentados, eram também frequentemente alvo de batidas da polícia.

A repressão policial era uma constante nos bailes, sempre exigindo dos frequentadores documentos comprobatórios da condição de trabalhador, não apenas carteira de identidade. A maioria dos blacks não possuía carteira de trabalho assinada, pois grande parte trabalhava no mercado informal, como camelôs, pedreiros, etc. Isso acarretava um grande número de detenções.

E o baile naquela época era muito perseguido porque foi na época da ditadura. Do regime militar a polícia não dava mole. Era 'mão na cabeça quem tem documento apresenta, quem não tem entra ali'. Quantas vezes a gente foi preso, a gente foi preso por quê? Porque a gente estava dançando, não estava fazendo nada de errado. A gente não se drogava, a gente nunca tinha visto droga na vida. Até hoje, não fumo nem bebo, eu só gosto de dançar. Então a gente ia preso à toa (RONALDO BLACK, 16 jun. 2007).

O declínio dos bailes black no Centro de Belo Horizonte pode ser creditado, principalmente, à repressão policial. De acordo com Antônio Marçal, o DJ Toninho Black, que hoje promove o maior baile da cidade, o Baile da Saudade, em Venda Nova, bairro periférico localizado na zona norte da cidade:

Na época teve muitas represálias não podia ter um baile soul que a polícia chegava com várias viaturas, parava o baile, dava geral, batia em pessoas que não tinham nada a ver. Eu mesmo na era Máscara Negra, quando o Som da Soul James foi para o Máscara Negra, eu mesmo fui um dos que cortei. Cortei de ir ao Máscara Negra um bom tempo por medo de tomar tapa da polícia. Na década de 70 a música negra era muito criticada no Brasil em geral. Então todo mundo achava que era o funk soul, o funk nosso, nós negão, eram umas músicas mais para marginal, mais para favelado, mais para pessoa que não presta (TONINHO BLACK, 12 fev. 2006).

Assim como o movimento Black-Rio, os bailes black foram perdendo sua força, seja pela repressão policial, seja pela sutileza da influência da mídia, com o advento da disco-music. O retorno do soul e do seu ideário de igualdade à cena urbana ainda demoraria quase 30 anos. 


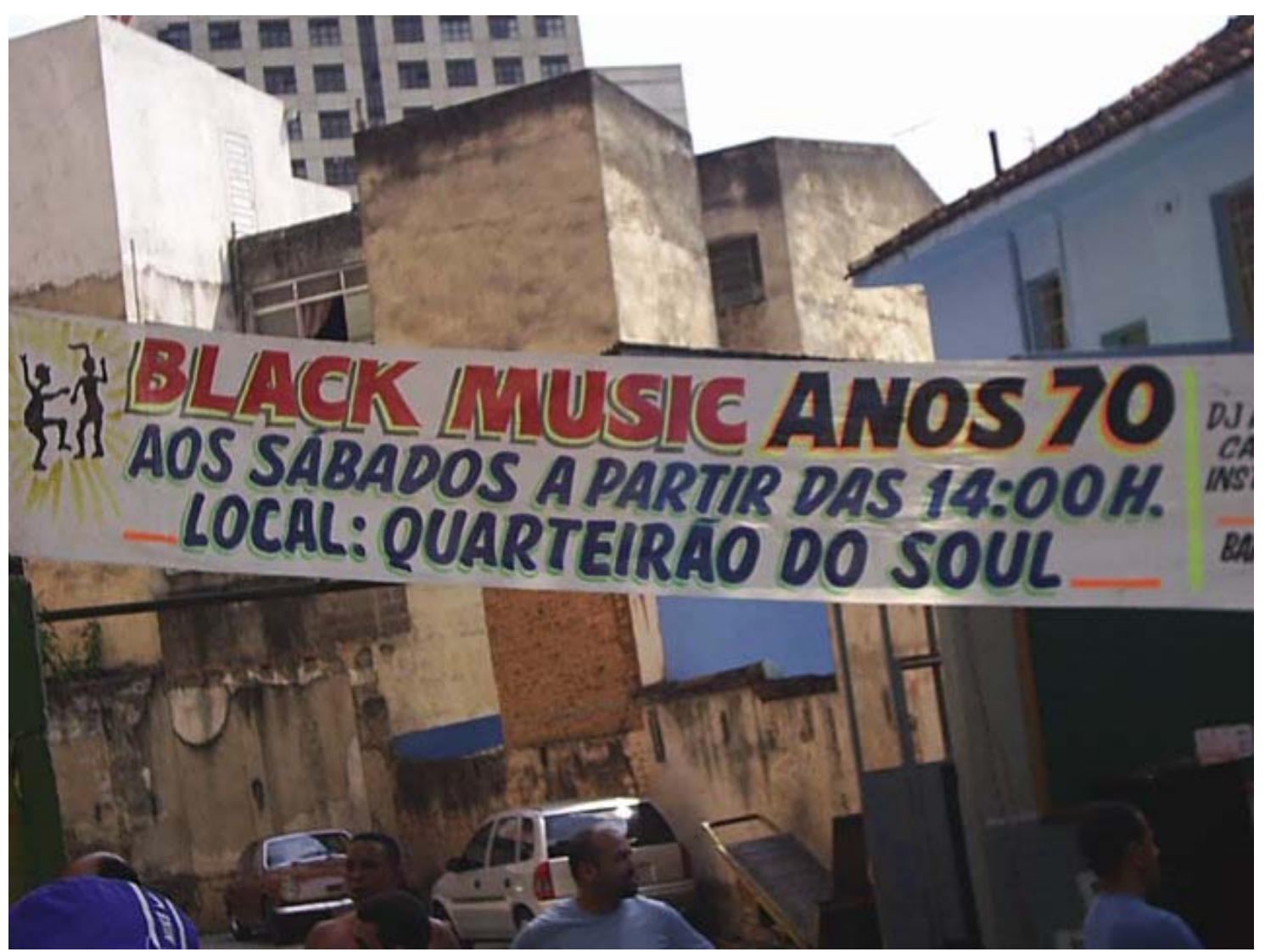

Figura 1 - O Quarteirão do Soul em BH. De volta às origens

Fonte: Quarteirão do Soul: o resgate da rua como espaço de cidadania.

O retorno do soul ao Centro de Belo Horizonte acontecerá somente em 2004. No dia 3 de abril de 2004, alguns amigos se encontraram no quarteirão da Rua Goitacazes, entre as ruas São Paulo e Padre Belchior, região central da cidade. A idéia do Quarteirão do Soul surgiu do encontro de sete amigos no local, onde um deles, Geraldo Antonio dos Santos, o DJ Geraldinho, lava carros. De acordo com Ronaldo Black, eles estavam com a Caravan (sua marca inicial) estacionada no local e começaram a dançar. Daí surgiu a idéia de "rever os velhos companheiros”. Para Valdeci, ou Abelha, “a gente quer resgatar o espírito jovem, o black não fica velho”. Os amigos fundadores da chamada "Diretoria” vieram dos locais mais distantes: Gugu, do bairro Vera Cruz, Zezinho do Planalto, Geraldinho do Casa Branca, Ronaldo Black, da cidade de Santa Luzia, O DJ - A Coisa, da cidade de Betim. Abelha, do Bairro São Geraldo e Goder, do bairro Sagrada Família. A localização central propiciou um ponto de encontro em um local até então praticamente sem movimento aos sábados.

O Quarteirão do Soul, o que é? É um resgate. Cada um pegou a missão de estar trazendo para ali as pessoas que freqüentaram esses bailes naquela época. Então assim, se você conheceu três pessoas que freqüentaram o baile nos anos 70 e 80 e essas pessoas estão vivas, eu não sei se essas pessoas 
estão vivas, mas você sabe. Então você vai se virar para levar uma das três lá que esse um vai fazer o segundo ir que vai fazer o terceiro ir, independente de já ter parado, independente de estar na igreja, independente de estar no samba. Uma hora, mais cedo ou mais tarde, ele vai chegar ali e quando ele chegar vai ver pessoas que conviveram com ele naquela época que estão totalmente diferentes daquilo que foram quando eles eram mais jovens, mas têm os traços. E é interessante você vê as pessoas chegando lá e olha um pro outro assim "Você não é o fulano de tal?" - "Sou! Você me conhece da onde?” - “Lá do Máscara, lá do Máscara...lá do União Síria, lá do clube de Damas” (DJ ACOISA, fevereiro de 2006.).

Ao som da soul music, que a princípio saía de duas pick-ups instaladas em uma Caravan aberta, e hoje são montadas no passeio, um grupo de pessoas de meia-idade dança na rua, fazendo coreografias que encantam e surpreendem pela agilidade.

Esses cinquentões que você está vendo aí a maioria ia (aos bailes). Porque quem frequenta o Quarteirão hoje é aquele mesmo pessoal daquela época. Porque aqui passam pessoas com a idade de 60 anos e gostam? Porque aquelas de 60 anos na década de 70 elas deveriam ter o quê 30, 20, 25. Então quer dizer eram jovens e eles estão vendo o que está acontecendo da época deles e matam a saudade que é uma coisa boa. O soul é bom. É respeito. E hoje em dia o baile black é uma representação para todos os movimentos que tem de respeito (RONALDO BLACK, 2007).

O Quarteirão do Soul surgiu como uma forma de se reencontrarem os amigos que frequentavam os chamados bailes black no centro da cidade nos anos 70 e que, com o passar dos anos, foram sendo expurgados para a periferia da cidade. A idéia de resgatar os amigos é um dos pontos principais que moveram a organização do espaço. Tal manifestação constitui uma forma de resistência, pois os participantes do Quarteirão do Soul se apropriaram do local, mesmo sem o aval da prefeitura, e também se caracteriza pela afirmação da identidade de seus participantes, que se espelham no discurso de igualdade pregado pelo movimento soul, representado principalmente pela figura do cantor James Brown, ícone presente em estampas de várias camisetas, que tem seus passos e vestimentas copiados e celebrados por todos os frequentadores do espaço.

Esse movimento Quarteirão do Soul foi lançado através de uma caravan que estava parada em cima daquela placa ali em baixo. Para quê? Simplesmente para resgatar as pessoas. Que da nossa época estão aí, mendigando, estão na base da droga. Estão escondidos no canto, não têm ninguém, não têm amigos, não têm nenhuma pessoa que possa chegar para elas e dar um convívio. Quantas pessoas já chegaram aqui e já choraram porque reencontraram velhos amigos? E hoje ele não tem amigo nenhum. É aqui que ele encontra o caminho dele. Aqui todo mundo chega, todo mundo aqui está por uma união, uma amizade. Chega aqui, pode ser o mais bonito ou o mais feio, pode ser o mais rico pode ser o mais pobre. Eles se unem aqui em torno da black music (CLÁUDIO, junho 2007.). 
A partir do gosto comum pela black music, e trazendo o ideário de igualdade e fraternidade do movimento soul, os amigos constituíram o Quarteirão do Soul. O público frequentador situa-se na faixa dos 40/50 anos, um fato intrigante quando se pensa que a maior parte dos movimentos de rua é encabeçada pela rebeldia juvenil. A maioria vem de bairros distantes do centro da cidade e pertence a classes economicamente desfavorecidas. Para o DJ Geraldinho, o mentor do movimento: “A idéia de criação do Quarteirão do Soul veio pela paixão pela música, pelo soul, pela dança, pela alegria e pela paz que ela traz para a gente” (SANTOS, 17/11/2007.).

A apropriação do espaço do Quarteirão do Soul ocorreu de forma espontânea. O poder público não foi consultado. Os frequentadores do local, capitaneados pelo lavador de carros que trabalha durante a semana naquele espaço, decidiram dar-lhe outra finalidade aos sábados. A comunicação entre os participantes se estabeleceu e contribuiu para o aumento da frequência ao espaço, que passou a se constituir como local de encontro e sociabilidade. A frequentadora Expedita Maria ${ }^{14}$, avó de quatro netos afirma:

Eu venho desde que o Quarteirão começou. Chego aqui às três e saio daqui sete horas. É muito chique e muito bacana minha amizades, eu amo meus amigos e as minhas músicas. Amo meu James Brown e amo a minha galera. A gente já curtia o som e ter iniciado o Quarteirão, para nós foi bom. Porque eu esperava uma vez no mês para poder ver. Depois eu fiquei esperta, falei o que, onde tiver James Brown eu tô indo. Ficar dentro de casa não. Chega no dia de eu ir curtir meu James Brown eu esqueço até que eu tenho família. (EXPEDITA, dezembro de 2006.).

Em 2005, o Quarteirão teve uma cisão entre os frequentadores e se criou outra vertente, o Movimento Black Soul. Esse desentendimento provocou o esvaziamento do movimento e sua quase extinção. No entanto, desde o início de 2006 houve um acerto entre o DJ Geraldinho e o representante do Movimento Black Soul, Abelha, ficando acertado que cada DJ tocaria em dois sábados do mês. Mesmo tendo passado por crises que culminaram no afastamento de alguns membros, sofrendo a intervenção da polícia em alguns tensos momentos, o Quarteirão do Soul vem resistindo. A cada dia vemos o seu público aumentar. Hoje ele ganha algum destaque na mídia e os frequentadores começam a receber novos adeptos, de todas as idades e vindos das mais diferentes regiões da cidade. Por ser um espaço

\footnotetext{
${ }^{14}$ Expedita morreu em janeiro de 2007. Teve um aneurisma enquanto decidia qual roupa usaria no baile da noite, em homenagem à memória de James Brown. Como era de família muito pobre, os frequentadores do Quarteirão se uniram para cobrir as despesas com o enterro.
} 
público, as pessoas que ali se reúnem, e agora já tomam não apenas a calçada, dançam em toda a rua, sentem-se participantes não apenas de um movimento, mas da vida da cidade.

O Quarteirão do Soul hoje representa um momento de exceção na vida cotidiana da cidade. Um momento de festa, da consagração da alegria do estar juntos, da possibilidade de, por alguns momentos, sair da condição de invisibilidade social, unidos pela paixão da soul music e pela utilização de um espaço, que ao mesmo tempo é de todos e não pertence a ninguém: a rua.

Tudo, porque minha dança eu comecei na rua, assim, comecei lavando carro e dançando, então na rua aqui isso para mim é minha casa, eu estou aqui praticamente confortável. Todo mundo que chegar aqui me vê dançando e eu trago alegria pra muita gente. Tem vez que eu não estou em condições de vir aqui porque estou passando mal, mal-estar porque eu trabalhei muito de manhã que eu trabalho no sábado, três anos que eu não tiro férias, muito cansado. Eu venho aqui para alegria do pessoal, dá muita alegria para o pessoal que passa dança igual aí, passa, para dar uma olhadinha, é uma coisa, mas aqui é a melhor coisa que teve em Belo Horizonte foi isso aqui, porque Belo Horizonte é um lugar é igual o pessoal do Rio, São Paulo fala, aqui é praticamente uma roça, mas não tem nada de roça não, nós somos muito inteligentes, o mineiro é muito inteligente e são os melhores dançarinos do Brasil e do mundo porque só aqui que existe isso (LOURINHO, 2007.)

O Quarteirão do Soul pode ser entendido como um movimento de uma pequena parcela de moradores da cidade, uma minoria. Muniz Sodré (2005), entretanto, apresenta uma interessante definição sobre o conceito de minoria. Para o autor, minoria seria uma voz qualitativa e não um conceito quantitativo, pois essa visão refere-se à possibilidade de um determinado segmento social ter voz ativa, ou capacidade para intervir nas instâncias decisórias do Poder. Por isso, negros, mulheres, ambientalistas, indígenas são considerados minorias. O "lugar" das minorias seria aquele onde se animam fluxos de transformação de uma identidade ou de uma relação de poder que implica uma tomada de decisão de um grupo no interior de uma determinada dinâmica de conflito.

Minoria, então, transforma-se em um conceito simbólico, dotado de uma intencionalidade ético-política inserida numa luta contra-hegemônica. Luta que se apresenta em várias instâncias da vida social, na cultura e na arte de um povo. Que tem na apropriação de um determinado gênero musical - a soul music - como manifestação de uma resistência que configura identidades e transforma, também, os sentidos de apropriação da cidade. 
A afirmação da identidade black é um elemento fundamental na apropriação do espaço do Quarteirão do Soul. Essa afirmação se faz presente no discurso dos seus frequentadores que se espelham em James Brown e que têm na moda, nos gestos, nas expressões da fala e na dança seus principais elementos distintivos. O movimento black tinha, em todo o País, características semelhantes. Desde as roupas, passando pelo cumprimento, gírias, postura dos dançarinos, que levaram à configuração desta identidade, que, ainda hoje, se constitui em sua peculiaridade, e se mantém presente nos bailes no País e nas ruas de Belo Horizonte nas tardes de sábado.

O Quarteirão do Soul, já no seu quinto ano de existência, representa um momento de exceção na vida cotidiana da cidade. Um momento de festa, da consagração da alegria do estar juntos, da possibilidade de, por alguns momentos, sair da condição de invisibilidade social, unidos pela paixão da soul music e pela utilização de um espaço, que ao mesmo tempo é de todos e não pertence a ninguém: a rua.

É também um resgate da cidadania, daqueles que são excluídos dos processos de consumo e de acesso aos bens simbólicos da cidade. Ele representa um retorno ao ideário difundido no País a partir do movimento Black-Rio e de seus diversos seguidores.

No entanto, gostaríamos de encerrar o artigo com a certeza de que o ideário do movimento black cruzou as fronteiras do racismo e ganhou o espaço das cidades. Infelizmente, esse não é o quadro que se delineia para os frequentadores do Quarteirão do Soul em 2009. Recentemente, os organizadores foram avisados pela prefeitura de Belo Horizonte que não poderão mais se reunir no seu espaço original. As razões são explicadas no manifesto em defesa do Quarteirão enviado pelo DJ Joseph, um dos DJs do movimento:

http://www.clicandoavida.com.br/Após ter se inteirado dos fatos, o que passa:

Alguns moradores incomodados com a diversão e talvez, até preconceito "racial" decidiram que não querem mais o evento no local, e alguém na prefeitura, mesmo com tudo legal: sempre temos licença da prefeitura; quando a fiscalização chegou de surpresa, a amplitude sonora estava abaixo do limite máximo.

O horário de término é, impreterivelmente, 20 horas: mesmo no dia em que comemorávamos o aniversário e a rua reunia mais de 1.000 pessoas, não passamos do horário.

Portanto, no que diz respeito à lei, estamos completamente regulares. Com isso, o que nos resta são os motivos mesquinhos do despeito (a alegria incomoda); e o preconceito (um bando de pobres, negros, sem o que fazer, tirando o "sossego dos nobres cidadãos").

E para piorar, querem enxotar-nos para um "quilombo" bem longe onde ninguém nos veja (rua Guaicurus esquina com Bahia ) com aquela conversa pagando de bonzinhos:

"Lá vocês terão (nunca foi dado ) todo o apoio!” 
Alguém tem que fazer alguma coisa por essa gente.

Alguém precisa defender essa gente.

Não podemos permitir que os negros sejam, em pleno século 2010, vítimas de tanto preconceito (DJ JOSEPH, $1^{\circ}$ set. 2009.).

Não podemos precisar qual será o destino do movimento: se ele está fadado ao desaparecimento, como o movimento Black-Rio, se conseguirá permanecer no local, se a mudança contribuirá para seu fortalecimento ou desagregação. Ressaltamos, porém, que a diáspora, a que frequentemente são submetidos os pobres das cidades, permanece. A luta pela igualdade é uma constante no urbano. Enquanto, por um lado, a arma é a música, por outro, ela é a lei. Pena que as regras sejam sempre tão desiguais.

\title{
WANDERING AND EXILE IN SOUL MUSIC: the Black-Rio movement in the 70's to the Quarteirão do Soul in Belo Horizonte, 2010
}

\begin{abstract}
The twentieth century witnessed several diasporas. Some of them clearly addressed by the vehicles of mass communication, others less so. This study addresses the emergence of a movement of affirmation of black identity in Brazil, the movement Black-Rio, which appeared in the mid-70s. It suffered persecution, not only on the political side, but also from the media, until its extinction in the same decade. The importance of the BlackRio was confirmed thirty years later, with the constitution of the Quarteirão do Soul in Belo Horizonte, a movement with similar ideology. It started downtown in 2004 with a group of friends, became a space of sociability and affirmation of black identity and, like its predecessor, begins to suffer harassment.
\end{abstract}

Keywords: Black identity. Soul music. Mass culture.

\section{Referências}

AQUINO, Maria Aparecida de. Censura, imprensa, estado autoritário (1968-1978). São Paulo: EDUSC, 1999.

ARAÚJO, Paulo César de. Eu não sou cachorro, não. Rio de Janeiro: Record, 2005.

BAHIANA, Ana Maria. Almanaque dos anos 70. Rio de Janeiro: Ediouro, 2006a.

Nada será como antes: MPB anos 70 - 30 anos depois. Rio de Janeiro: Ed. Senac-Rio, 2006b.

CASTELLS, Manuel. A sociedade em rede. A era da informação: economia, sociedade e cultura. São Paulo: Paz e Terra, 1999. v. 1.

O poder da identidade. São Paulo: Paz e Terra, 2002.

CHAUÍ, Marilena. Simulacro e poder. São Paulo: Editora da Fundação Perseu Abramo, 2006. 
DOPS: a lógica da desconfiança. 2 ed. Rio de Janeiro: Secretaria de Estado de Justiça; Aperj, 1996. $77 \mathrm{p}$.

ESSINGER, Silvio. Batidão: uma história do funk. Rio de Janeiro: Record, 2005.

FRIAS, Lena. Black Rio - O Orgulho (Importado) de Ser Negro no Brasil. Jornal do Brasil, Rio de Janeiro, 17 jul. 1976. Caderno B.

GIACOMINI, Sonia Maria. A alma da festa: família, etnicidade e projetos num clube social da Zona Norte do Rio de Janeiro - o Renascença Clube. Belo Horizonte: Ed. UFMG; Rio de Janeiro: IUPERJ, 2006.

INSTITUTO BRASILEIRO DE GEOGRAFIA E ESTATÍSTICA (IBGE). Anuário estatístico do Brasil 1959. Rio de Janeiro: IBGE, 1959. v. 20.

Anuário estatístico do Brasil 1970. Rio de Janeiro: IBGE, 1970. v. 31.

JORGE, Fernando. Cala a boca, jornalista! o ódio e a fúria dos mandões contra a imprensa brasileira. São Paulo: Novo Século, 2008.

KARNAL, Leandro et al. História dos Estados Unidos: das origens ao século XXI. São Paulo: Contexto, 2007.

KUCINSKI, Bernardo. Jornalistas e revolucionários. São Paulo: Ed. Página Aberta, 1991.

LEAMING, Bárbara. Orson Welles. Porto Alegre: L\&PM, 1987.

MELLO, Zuza Homem de. A era dos festivais: uma parábola. São Paulo: Ed. 34, 2003.

MIDANI, André. Música, ídolos e poder: do vinil ao download. Rio de Janeiro: Nova Fronteira, 2008.

MOTTA, Nelson. Noites tropicais. Rio de Janeiro: Objetiva, 2000.

Vale tudo: o som e a fúria de Tim Maia. Rio de Janeiro: Objetiva, 2007.

MUGGIATI, Roberto. Blues: da lama à fama. Rio de Janeiro: Ed. 34, 1995.

NOVAES, Adauto (Org.). Anos 70: ainda sob a tempestade. Rio de Janeiro: Ed. Senac Rio, 2005.

Os Arquivos das Polícias Políticas: reflexos de nossa história contemporânea. Arquivo Público do Estado do Rio de Janeiro. Rio de Janeiro, 1994.

ROCHA, Amara. Nas ondas da modernização: o rádio e a TV no Brasil de 1950 a 1970. Rio de Janeiro: FAPERJ, 2007.

SANTOS, Boaventura de Souza. Introdução a uma ciência pós-moderna. Rio de Janeiro: Graal, 1989.

SAUNDERS, Frances Stonor. Quem pagou a conta? Rio de Janeiro: Record, 2008.

SEVERIANO, Jairo; MELLO, Zuza Homem de. A canção no tempo: 85 anos de músicas brasileiras. São Paulo: Ed. 34, 1998. v. 2: 1958-1985.

SKIDMORE, Thomas E. Uma história do Brasil. São Paulo: Paz e Terra, 1998.

SODRÉ, Muniz. Claros e escuros: identidade, povo e mídia no Brasil. Petrópolis: Vozes, 1999. 
SODRÉ, Nelson Werneck. História da imprensa no Brasil. Rio de Janeiro: Mauad, 1999.

THAYER, Allen. Black Rio - Brazilian Soul and DJ Culture's Lost Chapter. Illustration by Alberto Forero. Revista Waxpoetics, New York, n. 16, abr./maio 2006. p. 88-106.

THOMPSON, John B. A midia e a modernidade: uma teoria social da mídia. Petrópolis: Vozes, 1998. Ideologia e cultura moderna. Petrópolis: Vozes, 2002.

VIANNA, Hermano. O mundo funk carioca. Rio de Janeiro: Jorge Zahar, 1988.

WILLIAMS, Raymond. Palavras-chave. São Paulo: Boitempo Editorial, 2007.

WOODWARD, Kathryn. Identidade e diferença: uma introdução teoria e conceitual. In: SILVA, Tomaz Tadeu da; HALL, Stuart; WOODWARD, Kathryn. Identidade e diferença: a perspectiva dos estudos culturais. Petrópolis: Vozes, 2000. p. 7-72. 